\title{
GCU
}

Glasgow Caledonian

University

University for the Common Good

\section{The promotion of arts and culture as a tool of economic regeneration: an opportunity or a threat to minority language development? The case of Gaelic in Scotland}

\section{Chalmers, Douglas}

Published in:

Rights, Promotion and Integration Issues for Minority Languages in Europe

Publication date:

2008

Document Version

Author accepted manuscript

Link to publication in ResearchOnline

Citation for published version (Harvard):

Chalmers, D 2008, The promotion of arts and culture as a tool of economic regeneration: an opportunity or a threat to minority language development? The case of Gaelic in Scotland. in S Pertot, TMS Priestly \& CH Williams (eds), Rights, Promotion and Integration Issues for Minority Languages in Europe. Palgrave Macmillan, pp. 141-164.

\section{General rights}

Copyright and moral rights for the publications made accessible in the public portal are retained by the authors and/or other copyright owners and it is a condition of accessing publications that users recognise and abide by the legal requirements associated with these rights.

Take down policy

If you believe that this document breaches copyright please view our takedown policy at https://edshare.gcu.ac.uk/id/eprint/5179 for details of how to contact us. 


\section{The Promotion of Arts and Culture as a Tool of Economic Regeneration: An Opportunity or a Threat to Minority Language Development? - The Case of Gaelic in Scotland Douglas Chalmers}

\section{Situation of Scotland and the Gaelic economy}

Peripherality

The Gaelic-speaking areas of Scotland face many of the problems endemic to peripheral, rural areas elsewhere in the European Union - depopulation, ageing communities and isolation (Chalmers and Danson, 2004). Traditionally, issues of high unemployment, underemployment and seasonality in the labour market have resulted in the prevalence of low wages and rural poverty in much of the area (Shucksmith, Chapman et al., 1996; Chapman, Phimister et al., 1998). One result of this has been continuing high levels of out-migration and depopulation. The traditional 'Gaelic heartland' (the Western Isles and parts of the Inner Hebrides of Scotland), have continued to be particularly badly hit up to the present day, with the population of Eilean Siar (the Western Isles) losing 10.5 per cent of its population between 1991 and 2001, and projected to lose another 16 per cent by 2018 . This has severe implications for the Gaelic-language-speaking community, with the General Registrar for Scotland reporting a loss of 19.6 per cent of its Gaelic speakers over the period 1991-2001 in the Western Isles (General Register Office for Scotland, 2004). In addition, the rapid intergenerational decline of Gaelic (which contrasts strongly with the more positive position in regard to the Welsh language in Wales) has led some commentators to call for "new philosophies, images, policies (which are) long overdue' (MacKinnon, 2004). Williams' welcome point (see Introduction to this volume) about the paradigmatic shift in Welsh from being seen as an instrument of social exclusion to that of a possible instrument of social 
inclusion has not yet reached policy makers within Scotland, although policy changes around the Gaelic Language Bill (see below) may herald that future possibility.

\section{Historical attitudes to the language and the area}

Until the 1960s, there was little in the way of conscious public policy to stem the loss of the Gaelic language in Scotland, registered through official Census figures as being in decline since the late 19th century. Nor was there a coherent approach to the specific economic problems faced by the populations of the Highlands and Islands. In relation to the language, Scottish Gaelic, like many other autochthonous languages, had suffered from decades of neglect, both benign and deliberate, often in the guise of support for 'modernism' and progress, the language being seen as an obstacle to full integration of the Highlands and Islands with the overwhelmingly English-speaking United Kingdom. As McLeod has illustrated, 'until the 1960s Gaelic language development was to all intents and purposes nonexistent'. He goes on to acknowledge that 'since then the rate of change has been rapid, even if the absolute level reached to date is still low' (McLeod, 2002). Coincidentally, only in the mid-1960s, with the growing recognition of market failure in the Highlands and Islands, was the first tentative acknowledgement given of the need for a more long-term developmental approach to economic change in this area (which comprised the bulk of Scotland's Gaelic-speaking communities). It was to be later that any possible link between language, arts and culture, and possible economic potential in terms of employment and overall development was acknowledged.

Although this acknowledgement was slow it was helped by the instigation in 1965 of an economic and social development agency to target the north of Scotland - the Highlands and Islands Development Board (HIDB). Unlike previous development bodies (and unlike any others created since), the HIDB acknowledged a specifically social remit amongst its economic aims - to improve both the economic and social conditions of the Highlands and 
Islands, and to enable the Highlands and Islands to play a more effective part in the economic and social development of the nation. In addition (and unlike other parts of what become known as the 'enterprise network' of local development bodies), the HIDB (and its successor - Highlands and Islands Enterprise (HIE)), was by statute legally obliged to consult with local authorities, the public, and other interested bodies when bringing forward proposals for economic and social development - an approach that compelled them to take some account of the linguistic and cultural differences within this area of Scotland.

The structure of economic development within the Highlands

Since 1991 Highlands and Islands Enterprise, together with Scottish Enterprise, have formed the core of the development network that aims to modernise the Scottish economy and promote business development in line with the priorities originally of the Westminster Parliament, but now mediated through the Scottish Government and Scottish Parliament - the devolved authority in Edinburgh set up in 1999.

HIE consists of ten local area networks - ranging from Western Isles Enterprise (WIE), working in an environment where 60 per cent of the population speak Gaelic, to areas such as Orkney Enterprise and Shetland Enterprise - based in the Northern Isles of the UK, where Gaelic influence is minimal to non-existent - the cultural roots of these islands lying rather with the Norse countries.

Each local area network operates according to a common set of overall targets and aims that are contextualised however, according to local circumstances.

Together with the development department of each local government district they are the main bodies responsible for helping manage economic change in their locality. Although the neo-liberal turn in UK government under the Thatcher administration (1979-1990) witnessed a transformation of the existing network towards a less interventionist, more 'entrepreneurial' model than previously, HIE has continued to maintain a more holistic approach to the 
acknowledged special conditions existing in the Highlands and Islands, with the theme of 'strengthening communities' remaining its top priority (Strengthening Communities, HIE, 1999). As many of these communities are Gaelic-speaking, the language and culture are officially stated to be a key aspect of development.

\section{Developments in Gaelic language policy}

At approximately the same time as the UK government acknowledged the special problems of the Highlands and Islands, resulting in the instigation of the HIDB, the first evidence of a change of attitude towards the Gaelic language began to be seen in policy-making circles including, importantly, educational provision. McLeod (2002) has outlined the gradual change in attitude from one of outright hostility to the acknowledgement of the need for comprehensive measures (see also Chalmers, 2003). Nevertheless, a note of despair could still be heard in the MacPherson Report as recently as 2002: 'Despite some significant successes, beneath a façade of well-being introduced by palliative measures, Gaelic is a critically ill patient on life support ... the prognosis is bleak' (MacPherson, 2002). Other, more positive (if still hard-hitting) assessments have been made following the establishment of a Gaelic development agency, the Bòrd na Gàidhlig (see below) and the passing into law of the Gaelic Language Act. While these changes are undoubtedly positive and necessary, they are only part of the type of far-reaching cultural change which will undoubtedly be needed in the longer term if the language is to flourish, moving from a formal acknowledgement to the adoption of a 'sensitised and supportive' approach (see Williams, this volume, Introduction, p. 17).

\section{Consideration of the link between language and the economy}

The first major review of the situation of the Scottish Gaelic-speaking communities that acknowledged the possible link between the fate of the Gaelic language and economic factors, was the Cor na Gàidhlig report in 1984 (MacKay, 1984) instigated by the Highlands 
and Islands Development Board. This resulted in the formation of the then main Gaelic development agency Comunn na Gàidhlig $(\mathrm{CnaG})$, with as one of its main remits, 'working at the interface between the linguistic and the social, cultural and economic aspects of development' (MacKay, 1984, p. 6). Amongst the proposals put forward in the report were:

exploiting the potential for Gaelic tourism; studying the future implications of video and audio visual technologies for the health of the Gaelic communities; investigation of the market for Gaelic arts and culturally related objects; development of an annual festival in addition to the existing 'National Mod'; and close attention to the growing local festival (Fèisean ${ }^{1}$ ) movement. (MacKay, 1984)

Although Gaelic language, arts and culture (GLAC) was not yet appreciated as a possible motor for development the report also recommended that:

cultural and linguistic dimensions should be considered along with social and economic factors in any realistic holistic view of community and regional development, and that accordingly the HIDB should examine its development policies with a view to allowing these dimensions to feature in the consideration of development policies. (MacKay, 1984)

Following the publication of Cor na Gàidhlig, 1993 saw a report on The Dynamics of Gaelic Development for HIE, the successor organisation to HIDB, where a call was made to 'consolidate and increase the provision of Gaelic television' (which had recently received its major boost in Gaelic-related funding), and for the development of 'Gaelic tourism' - closely integrated with recent developments in Gaelic arts and broadcasting (Pedersen, 1993). Where necessary, this would entail 'effective training to be provided in a variety of areas from the acquisition of Gaelic, to skills appropriate to the emerging Gaelic industries'. The report also 
called for 'strategic co-ordination through institutional support' and for 'an early review of how best to focus, co-ordinate and resource the management of Gaelic development to achieve maximum effectiveness' (Pedersen, 1993). The strategy subsequently adopted by HIE had as its stated aim 'The development of the Gaelic language and culture as a means of raising self-confidence and stimulating economic and social development' (Lingard, Pedersen et al., 1993). Specifically, provision was to be made for:

[t]he Gaelic Arts as a means of reinforcing the creation of a new Gaelic broadcasting industry; Gaelic development including training and business growth; and the integration of Gaelic into the tourist industry. (Pedersen, 1993)

In this period, Comunn na Gàidhlig adopted as two of its priority areas cultural development and economic development (together with Gaelic education and promotion). Within this, the development of the National Gaelic Arts Project and the Fèisean (local festival) were highlighted, with the acknowledgment that 'cultural expression is ... an important driving force for economic development' (Pedersen, 1995). Again the development of Gaelic tourism was highlighted, with note being taken of the need to address both 'internal Gaelic tourism' aimed at those already speaking Gaelic, and a 'volume market' comprised of visitors from outside the Highlands and Islands area, attracted by a hoped-for growing interest in all things Gaelic and Celtic. With regard to Gaelic tourism, it was envisioned that this would be private-sector-led, but supported by funding partnerships involving the HIE and Scottish Enterprise networks and others.

The background to this focus on economic development was an increasing appreciation of the opportunities afforded by the expanded Gaelic television coverage now coming on line (Sproull and Ashcroft, 1993). ${ }^{2}$ 
The early 1990s had seen the appearance of a seminal work by Sproull and Ashcroft (1993) who aimed to quantify for the first time the economic impact of what they categorised as the 'Gaelic industry' - all Gaelic-related economic activities, or 'all those activities (and jobs) whose principal purpose is the provision of Gaelic related goods and services, including the Gaelic culture and language'. This they worked out (with relevant multipliers) to be the addition of $£ 41 \mathrm{~m}$ (at 1992 prices) to the output of the economy and the creation of almost 1,000 full-time equivalent jobs (FTEs) within the Gaelic economy. The latter was defined as 'the spatial area which stands to gain measurable economic benefits from enhancing the status of the language'. Further research by Sproull and Chalmers (Sproull and Chalmers, 1998; Chalmers, 2003) investigated the particular contribution of the artistic and cultural sub-sector of the 'Gaelic economy' in terms of jobs and other economically significant impacts. In terms of jobs, Chalmers suggested that this activity created between 215 and 230 FTEs, and perhaps more importantly set in motion a whole range of dynamics in the local economy - an area previously suggested for further research by Sproull.

The following sections will investigate some of the questions raised in regard to the perceived interactions between arts, language, and the economy, and will consider some issues raised by this and suggest areas for further research.

\section{The suggested dynamics of culture and the economy}

Sproull had suggested that a set of dynamic effects might arise from the enhanced status of the language which could impact on social cohesion, on cultural expression, on artistic/musical output and on individual and community self-confidence.

If these links existed then enhanced language status might stimulate future enterprise, raise the quality of arts and entertainment, open up opportunities for cultural tourism, reduce outmigration, stimulate in-migration and alter the skills/income profile of local economies. 
Although these links might intuitively be suggested, Sproull had proposed that 'any argument that Gaelic language development can positively influence the long term health of the area defined as the "Gaelic economy" had to demonstrate that language development had an impact on one or more of a series of intermediate variables which were, in turn linked to economic growth'. (Sproull, 1993 p 34) These 'variables', he suggested, included the decision by residents to migrate or stay in the area, the decision to return or not by those who have left the area for education, training or for other reasons; the decision by local residents or incomers to start businesses in the area; the decision by tourists to visit the area; and the decision by companies external to the area to locate there.

It was argued that lying behind these decisions were a number of key propositions relating to identification, distinctiveness and self-confidence.

In short, it was suggested that in Gaelic Scotland dynamic language-economy linkages appeared to operate through intermediate variables such as an individual's sense of identity with place (influencing migration and business start-up decisions) and their sense of selfconfidence and pride in their own Gaelic identity (influencing business activity and tourism via the strength of the distinctive cultural 'products' tourists experience when visiting). It is these intermediate variables that appeared to be significantly influenced by artistic and cultural activities.

Although acknowledgement of the Irish formula of 'no jobs, no people; no people, no Gaeltacht' (Williams, 1988) had seemed to clearly suggest that a positive synergy could be forged between the two voices of economic development and language development - both long-term concerns within the area of the 'Gaelic economy', the work undertaken by Sproull, Chalmers and others suggested that the argument for the language-economy link was actually much more complex than a simple one of direct jobs impact. Behind the approach was the belief that 'culture could play a critical role in human development through its effect on 
identity and confidence, and even its job creation aspects and marketability'. (Chalmers 2003:

23) This idea - that culture has a basic connection with economic and social potential and

opportunities - in fact became an important approach in the 1980s. Within the debate on

Gaelic language development it became an area of further research, and as indicated below,

also of some disagreement.

Research by Chalmers (2003) did indeed seem to justify the positive linkage suggested by Sproull's initial work, with a major study and survey (comprised of very detailed responses from 6 per cent of the population of the 'Gaelic economy' - over 2,000 detailed responses) suggesting agreement between the practitioners/ suppliers of Gaelic arts and culture, the business community and a representative cross-section of the community within the 'Gaelic economy' that the posited indirect impacts were of some significance. Some of the findings of Chalmers' work are briefly indicated in Tables 8.1 and 8.2.

Table 8.1 Perceived impact of the provision of Gaelic-related artistic and cultural products and services

\begin{tabular}{lll}
\hline Aspect & Specific manifestation & Additional comments \\
\hline $\begin{array}{l}\text { Cultural distinctiveness / } \\
\text { self-confidence }\end{array}$ & $\begin{array}{l}\text { Communities appeared more self- } \\
\text { confident }\end{array}$ & $\begin{array}{l}\text { This was seen to have reversed a } \\
\text { trend of declining self-confidence } \\
\text { in the past }\end{array}$ \\
\hline $\begin{array}{l}\text { Building a 'dynamic } \\
\text { relationship' }\end{array}$ & $\begin{array}{l}\text { Economic/cultural investment seen to } \\
\text { lead to 'community response' } \\
\text { Creation of a greater level of self- } \\
\text { sustaining organisations in } \\
\text { communities }\end{array}$ & $\begin{array}{l}\text { Attitudes in 'second-generation' } \\
\text { parents notably impacted positively }\end{array}$ \\
\hline Full-capacity working & $\begin{array}{l}\text { Some support organisations working } \\
\text { at full capacity }\end{array}$ & $\begin{array}{l}\text { Knock-on demand for further } \\
\text { investment }\end{array}$ \\
\hline Employment & $\begin{array}{l}\text { Jobs continued to be seen as } \\
\text { 'paramount' in rebuilding } \\
\text { communities }\end{array}$ & $\begin{array}{l}\text { Initial involvement in community } \\
\text { culture led to openings in larger } \\
\text { media organisations }\end{array}$ \\
\hline $\begin{array}{l}\text { Desirability of residence in } \\
\text { Gaelic-speaking areas }\end{array}$ & $\begin{array}{l}\text { Majority of organisations perceived } \\
\text { residence as a positive enhancement }\end{array}$ & $\begin{array}{l}\text { Some organisations noted difficulty } \\
\text { of quantification; long-term factor } \\
\text { seen as key }\end{array}$ \\
\hline Migration & $\begin{array}{l}\text { Some reports of positive impact } \\
\text { Feeling of more work needing to be } \\
\text { done on this }\end{array}$ & $\begin{array}{l}\text { Acquisition of GLAC*-related } \\
\text { skills could lead to greater mobility } \\
\text { and thus migration }\end{array}$ \\
\hline Tourism & $\begin{array}{l}\text { Similar perception to that regarding } \\
\text { migration. Feeling of a lot more work } \\
\text { needing to be done }\end{array}$ & \\
& & \\
\hline
\end{tabular}

* GLAC Gaelic language, arts and culture

Indeed it appeared to be the case that exposure to ('consumption of') Gaelic language, arts and culturally related goods had an increasingly positive effect on a whole range of the crucial variables under study.

Table 8.2 Perceived impact of GLAC*-related exposure/consumption

\begin{tabular}{lllllllll}
\hline Factor & \multicolumn{7}{c}{ 'Units' of consumption } \\
\hline & Nil & 1 or & 2 or & 3 or & 4 or & 5 or & 6 \\
& & more & more & more & more & more & \\
\hline
\end{tabular}

Percentage of respondents who believe the consumption of GLAC has 'greatly 


\begin{tabular}{|c|c|c|c|c|c|c|c|}
\hline \multicolumn{8}{|l|}{$\begin{array}{l}\text { increased'/ 'slightly increased' the } \\
\text { following: }\end{array}$} \\
\hline $\begin{array}{l}\text { The regularity with which Gaelic is used in } \\
\text { the local community }\end{array}$ & $30 \%$ & $55 \%$ & $58 \%$ & $61 \%$ & $64 \%$ & $66 \%$ & $69 \%$ \\
\hline $\begin{array}{l}\text { The regularity with which Gaelic is used in } \\
\text { local families }\end{array}$ & $23 \%$ & $49 \%$ & $53 \%$ & $56 \%$ & $58 \%$ & $61 \%$ & $62 \%$ \\
\hline The attractiveness of the area to tourists & $40 \%$ & $64 \%$ & $65 \%$ & $68 \%$ & $69 \%$ & $70 \%$ & $71 \%$ \\
\hline $\begin{array}{l}\text { The attachment of local people to their } \\
\text { community }\end{array}$ & $23 \%$ & $49 \%$ & $51 \%$ & $53 \%$ & $56 \%$ & $57 \%$ & $58 \%$ \\
\hline $\begin{array}{l}\text { The level of confidence within your local } \\
\text { community }\end{array}$ & $23 \%$ & $45 \%$ & $47 \%$ & $49 \%$ & $52 \%$ & $54 \%$ & $55 \%$ \\
\hline $\begin{array}{l}\text { The preference of individuals within your } \\
\text { community to choose/ purchase Gaelic } \\
\text { services/ products where possible }\end{array}$ & $26 \%$ & $54 \%$ & $56 \%$ & $58 \%$ & $61 \%$ & $63 \%$ & $65 \%$ \\
\hline \multirow[t]{2}{*}{ Factor } & \multicolumn{7}{|c|}{ 'Units' of consumption } \\
\hline & Nil & $\begin{array}{l}1 \text { or } \\
\text { more }\end{array}$ & $\begin{array}{l}2 \text { or } \\
\text { more }\end{array}$ & $\begin{array}{l}3 \text { or } \\
\text { more }\end{array}$ & $\begin{array}{l}4 \text { or } \\
\text { more }\end{array}$ & $\begin{array}{l}5 \text { or } \\
\text { more }\end{array}$ & 6 \\
\hline \multicolumn{8}{|l|}{$\begin{array}{l}\text { Percentage of respondents who 'strongly } \\
\text { agree' / 'agree' with the following } \\
\text { statements: }\end{array}$} \\
\hline $\begin{array}{l}\text { The regeneration of Gaelic language, art and } \\
\text { culture is essential for the future social } \\
\text { development of your own area / island } \\
\text { group }\end{array}$ & $37 \%$ & $72 \%$ & $76 \%$ & $78 \%$ & $81 \%$ & $82 \%$ & $87 \%$ \\
\hline $\begin{array}{l}\text { The regeneration of Gaelic language, art and } \\
\text { culture is essential for the future economic } \\
\text { development of your own area / island } \\
\text { group }\end{array}$ & $29 \%$ & $63 \%$ & $66 \%$ & $69 \%$ & $71 \%$ & $73 \%$ & $77 \%$ \\
\hline $\begin{array}{l}\text { The development of Gaelic language, arts } \\
\text { and culture is making an important } \\
\text { contribution to the level of self-confidence } \\
\text { in your own area / island group }\end{array}$ & $33 \%$ & $62 \%$ & $65 \%$ & $68 \%$ & $72 \%$ & $74 \%$ & $79 \%$ \\
\hline $\begin{array}{l}\text { The development of Gaelic language, arts } \\
\text { and culture is increasing the attractiveness } \\
\text { of your area to tourists }\end{array}$ & $36 \%$ & $68 \%$ & $71 \%$ & $73 \%$ & $75 \%$ & $76 \%$ & $79 \%$ \\
\hline $\begin{array}{l}\text { The development of Gaelic language, arts } \\
\text { and culture is increasing the desire of young } \\
\text { people to live and work in their home area }\end{array}$ & $24 \%$ & $49 \%$ & $51 \%$ & $53 \%$ & $56 \%$ & $57 \%$ & $61 \%$ \\
\hline $\begin{array}{l}\text { The development of Gaelic language, arts } \\
\text { and culture is broadening the range of } \\
\text { employment opportunities which exist for } \\
\text { people locally }\end{array}$ & $38 \%$ & $70 \%$ & $73 \%$ & $76 \%$ & $79 \%$ & $80 \%$ & $83 \%$ \\
\hline $\begin{array}{l}\text { Taking local and national factors into } \\
\text { account, I am optimistic about the future } \\
\text { health and development of the Gaelic } \\
\text { language }\end{array}$ & $39 \%$ & $67 \%$ & $69 \%$ & $71 \%$ & $73 \%$ & $76 \%$ & $76 \%$ \\
\hline
\end{tabular}

* GLAC Gaelic language, arts and culture

The key implication of Table 8.2 is that of a discernible increase in the perceived importance of GLAC-related activity as the consumption of / involvement with such activity increases. A cross-section of businesses (both Gaelic and non-Gaelic) similarly viewed the effects of GLAC consumption in a positive light, with the community's perception of the impact of GLAC exposure/consumption on crucial developmental variables also appearing to be positive (see Chalmers, 2003).

Given the comprehensive and apparently representative nature of the responses, ${ }^{3}$ this appeared to strengthen the case for a positive synergy. 


\section{Criticisms of any necessary equivalence between economic, cultural and language development}

Some important criticisms of these conclusions have however been made by a body of opinion within the language regeneration community which offers a more cautionary approach to any necessary positive synergy between linguistic and economic development. Perhaps the most representative examples of the range of these critical voices may be illustrated in the work of Caimbeul, MacLeod, and Lang (Caimbeul, 2000; McLeod, 2001a, 2001b, 2002; Lang, 2006), who raise concerns regarding several aspects of the envisaged linkage.

While acknowledging the Irish formula 'no jobs, no people; no people, no Gaeltacht', McLeod criticises any tendency to see economic development as a substitute for a robust language policy, and points out the possible negative effects of increased jobs, leading to a decrease in Gaelic speakers and the lessening of intergenerational transmission of the language - increase of the latter being seen by Fishman as key to language regeneration (Fishman, 1990). In this he echoes cautions raised years earlier by Keane and Griffith and MacKinnon amongst others, who drew attention to the 'uneasy relationship between culture and economic development' (MacKinnon, 1992, 1997; Keane, Griffith et al., 1993). Although a well-known study by Prattis (1983), instanced the case of increased oil fabrication in Lewis as bringing about a return of Gaelic speakers, the lack of similar, well-known studies might suggest that this important example was the exception rather than the rule. In addition, McLeod feels that the most fundamental problem with what he refers to as the 'rhetoric of the Gaelic economy' is that it creates the expectation of direct pay-offs in the form of employment opportunities, and he believes it is judged primarily on this and only secondarily on the expected linguistic impact. This is given a sympathetic appraisal by Caimbeul (2000), who fears that what was once a family culture may soon become only 'a career option or a marketing tool'. Essentially McLeod and others are suggesting that unless 
economic development programmes and strategies are designed with an explicit languageplanning component, there is a real risk of undermining the language community traditionally marginalised from economic activity - in this case the Gaelic-speaking community. In support of this approach McLeod notes that even in areas of currently high minority language use - such as the Western Isles and Skye and Lochalsh (which might lead one to expect a higher acknowledgement of the positive attributes of bilingualism, or of the minority language) - complacency is often found in relation to employment policy and there appears to be little awareness of any impact on minority language use through disglossia. Evidence for this is proposed in McLeod's analysis of job advertisements over an 18-month period in the Western Isles and Isle of Skye. Here, local authorities (a main employer) were found to be poor in terms of any acknowledgement of language dimensions to employment. In the Western Isles, of 257 jobs advertised, less than 5 per cent were advertised as 'Gaelic essential' (2.5 per cent) or 'Gaelic desirable' ( 2.3 per cent). Similarly, in the Isle of Skye, only 13 per cent of local authority jobs were so designated.

Of community and economic development jobs (49), none were designated as 'Gaelic essential', with 30 per cent designated as 'Gaelic desirable'. It was found that references to Gaelic were almost completely excluded from the health, social service and voluntary sectors despite the high Gaelic-speaking profile of those needing such services. Finally, Gaelic was almost completely excluded from the private, for-profit, commercial sector (McLeod, 2001b). Clearly this suggests that there is a case to answer here which those working in the fields of language development and of the economy need to be aware of. The approach of Lang (2006) raises a wider, although perhaps linked issue which questions the efficacy of investment in some areas of minority arts and culture. She raises concern that the generic term 'Gaelic arts and culture' may in some cases refer to artistic and cultural 
expression or activity that she sees as having very tenuous links to the language, and the funding of which may lead to little if any positive impact on language regeneration.

In a paper presented to the 3rd conference on Research in Gaelic in July 2005, she suggested that the majority of arts projects 'do not fulfil language planning aims at all with regard to corpus, acquisition or usage planning ... we are surrounded in the world of Gaelic arts by missed opportunities for Gaelic language use'. (Lang, 2006: 203) She also quotes, in a similar vein, MacCaluim and McLeod who restate the issue in a stark manner in their view of the funding of the 'Gaelic arts':

Ignored is the basic definitional question as to which entities constitute 'Gaelic' groups and which public funding constitutes 'public funding of Gaelic'. This is a question of substantial importance given that a range of groups and projects receive public funding to support 'Gaelic culture' or 'the Gaelic arts' but actually make minimal use of Gaelic in their work or cater for largely monolingual English-speaking audiences. The issue of the relationship between cultural projects and the development of the Gaelic language is simply not addressed. (MacCaluim and McLeod, 2001)

In short, Lang's view would appear to be that if a reversal of language shift is to be achieved, 'the emphasis must be on Gaelic as a language rather than as a hallmark/brand that is used to achieve other ends', and she finishes her paper by suggesting that 'RLS [reversing language shift] efforts can be integrated into Gaelic arts projects, but this will not happen naturally, and it is not happening at the moment' (Lang 2006: 209).

\section{Areas for further investigation}

In light of these issues, and other similar fears raised by individuals active in the language development community with regard to the net benefits or disbenefits of the economy/culture/language link, a case clearly exists for further research into this area. 
At issue seem to be several questions. Firstly, is there an awareness by policy practitioners of the growing body of evidence linking the fields of language, culture and economic development and their complex interactions (or is it indeed naively imagined that job creation in a geographical area of minority language use will simply lead to a regeneration of the language as a natural outcome)? In fact does the issue of language impact register at all in the appraisal of the bodies afforded the job of local economic development? Or, as with the general ignorance of the European Charter for Regional or Minority Languages found within most UK public bodies, is this something not even on the register of most policy practitioners? (see McLeod, this volume, Chapter 3).

Secondly, how might any recognition of such a link be reflected in staff training or development in relation to knowledge of language planning or personal linguistic ability in the minority language? Finally, from a somewhat wider perspective, given the view of Chalmers and others on the importance of the minority language artistic and cultural sector and its interaction with economic and social development ('much more complex than a simple one of direct jobs impact'), is there any particular acknowledgement given to this sector's complex role in the long-term economic regeneration of a locality?

The remainder of this chapter outlines the results of some preliminary investigations by the author into these issues.

\section{Investigation methodology}

In furtherance of the above enquiry, additional primary research was conducted in early 2005 with a series of elite interviews undertaken with a wide range of key individuals within the economic and arts support organisations, whose remit covered the geographical areas under study.

Within the enterprise network (HIE), the responsibilities for community development and social aspects of economic development lie with the Community Development Teams. Key 
personnel were identified within each of the local enterprise organisations who had responsibility for this area and who could give a considered point of view of the issues under investigation. The head of Heritage and Cultural Development for the network also agreed to be interviewed. Similarly, the economic development officer in the major local government district was also approached for his views.

In addition to interviews with those given direct responsibility for economic development, interviews were also held with the chief executive of the Gaelic Development Agency (Bòrd na Gàidhlig), and the director of the Gaelic Arts Agency - formerly the National Gaelic Arts Project (Pròiseact nan Ealan) regarding their views on the issues in question. Lack of time unfortunately precluded an interview with a representative of the Gaelic Broadcasting Service (Seirbheis nam Meadhanan Gàidhlig), which would have also afforded valuable information, given the pre-eminent role of the Gaelic media, both as a Gaelic window on the world, and also as a source of high-quality employment for Gaels and non-Gaels.

These interviews took place against a background of evolving policy regarding the development of the Gaelic language. The policy developments were closely associated with the new Gaelic Language Bill passed by the Scottish Parliament in April 2005 and its implementation by the newly established Bòrd na Gàidhlig (see below). Given these circumstances, the evolving strategic plan of the Bòrd na Gàidhlig and current policies of the Gaelic Arts Agency were therefore also examined to allow any synergies between the Bòrd's approach and those of the economic and artistic/cultural bodies to be ascertained.

\section{The approach of the Bòrd na Gàidhlig}

The Bòrd na Gàidhlig (Gaelic Development Agency, henceforth BnaG) was established in 2004 with responsibility for 'the overall direction and management of the language plan for Gaelic' in Scotland (see www.bord-na-gaidhlig.org.uk). 
In focusing delivery of the above mission, BnaG has agreed a set of aims which include 'extending and enhancing the use of Gaelic in all aspects of life in Scotland'. Amongst the Bòrd's objectives are: 'preparing a plan for Gaelic development in Scotland; promoting and facilitating use of the Gaelic language; and distributing grants to promote and facilitate the use of Gaelic'.

The activities of the Bòrd include 'setting performance indicators for itself and the bodies it supports', and 'monitoring and evaluating its contribution and that of the bodies it supports'.

It also aims to 'propose levels of service to be achieved in key areas and [collect] performance and outcome information [which] will be ... analysed to monitor progress'. (BnG online) The key targets and performance measures are to be established annually and agreed between the Bòrd and Ministers.

The aims are seen as being achieved by pursuing three strategic priorities:

- growing education and learning to build a new Gaelic-speaking generation;

- developing culture and arts to enrich Gaelic life;

- promoting economic and social development to maintain the Gaelic community.

Within the Gaelic Language Bill, however, the powers conferred on the Bòrd in relation to culture are minimal, consisting of 'advising [interested parties] on matters ... relating to Gaelic culture' and 'facilitating access ... to ... Gaelic culture'. No special role is assigned to culture in the framework of promoting the language (see Kidner, 2004).

\section{Economic development bodies}

As mentioned above, Highlands and Islands Enterprise operates throughout the Highlands and Islands of Scotland with several local enterprise companies (LECs) covering areas where from a quarter to almost two thirds of population speak Gaelic.

In other areas the Gaelic tradition is historically less strong, or has become negligible over the last century. Interviews therefore took place with representatives of the Community 
Development sections of the enterprise network in the geographical areas where a noticeable percentage of the population still speak or understand Gaelic. These were: Western Isles Enterprise (WIE); Skye and Lochalsh Enterprise (SLE); Lochaber Enterprise; Argyle and Islands Enterprise; Ross and Cromarty Enterprise; and Inverness and Nairn Enterprise (this interview involved the chief executive).

In addition, interviews took place, as already mentioned, with the head of Heritage and Cultural Development for the network as a whole, and one of his senior Gaelic-speaking members of staff. Finally, in relation to the enterprise network, the head of the Uist-based data-processing network (situated in a Gaelic-speaking area) was also interviewed. To collate the opinions of others involved in economic development, the Economic Development Officer in the main Gaelic-speaking area - the Western Isles Council - was also interviewed.

The individuals mentioned above were asked a range of questions, on their own background, the aims of their organisation, the attitude of the organisation to the role of the Gaelic language in the organisation's day-to-day internal running, and how the organisation positioned itself (if at all) in relation to specific language and cultural development issues. Table 8.3 summarises the responses. The specific questions included:

- Does the organisation have a specific language policy (or plan to have one)?

- Do members of staff have specific knowledge of language-planning issues?

- Does the organisation have an attitude to the issue of bilingual staff / training in the minority language / instances where the minority language 'ought' to be used? On these issues, why has the organisation's specific policy evolved in the way it has?

- Does the organisation keep records of the staff's language abilities? 
- Does the promotion of Gaelic language, arts and culture feature in the aims of the organisation? If so, what level of importance does it have?

- Does a client body's attitude to Gaelic language, arts and culture feature in whether it might be funded, and to what level? What criteria are involved in funding decisions?

- Does any monitoring of the language impact of funding decisions take place?

- Is it possible to determine the proportion of monies/aid given to Gaelic language, arts and culture-related organisations?

- Does the organisation have any awareness of the pending impact of the Gaelic Language Bill?

- What are your personal views on the importance of Gaelic language, arts and culture for the social and for the economic development of the area?

\section{How aware are policy makers of any dynamic interaction (positive or negative) between economic development and culture/language issues?}

As shown in Table 8.3, in relation to awareness of theoretical or practical aspects of language planning (and thus any interaction with economic development), the picture was very mixed, and seemed to be very dependent on how geographically close the organisation was to the Gaelic heartland and to Gaelic 'visibility'; how the remit of the organisation was seen; and the individual commitment of the particular individuals carrying out the day-to-day work of the organisation. Whilst the Western Isles Council had a very detailed language policy and believed that its method of inter-agency community-planning partnerships was a very practical and positive example of how to build the language and the economy together, the local enterprise companies tended to operate in a less holistic manner, with some very committed staff (particularly those who had a remit dealing with culture and heritage) working with others whose view of the links of Gaelic and the economy was less developed. In most cases the appreciation of any language-economy link was extremely underdeveloped. 
Where staff in the LECs had any knowledge of language planning issues it tended to be because of their own personal commitment to the language or to community involvement outwith the organisation. The LECs, as part of a centralised organisation, had no scope for independent approaches to language policy, and tended to wait on a central policy being decided and disseminated to the constituent parts of the network. How a particular part of the network related to the issue of the language also seemed to depend greatly on how positive senior members of staff were in relation to the issue.

Having acknowledged this, the network was currently undertaking a major rewriting of its Gaelic language policy in line with the requirements of the Gaelic Language Bill, with those responsible optimistic about the changes this would bring about.

In relation to policies on bilingual staff, rarely was this a prerequisite (found only in relation to Culture and Heritage), although resources were provided in all cases for staff who wished to become bilingual. Except in a few instances, however, this was demand-led from the individual, and it was not a presumption of the organisation that staff ought to become conversant with the minority language. In the Western Isles organisations, the presumption tended to be that Gaelic speakers could be found for most posts, but outwith the Western Isles, fear was expressed that that such a 'constraint' might 'limit the field' for applicants, in geographical areas where the labour market was already competitive and tight.

In terms of demand from clients for Gaelic-speaking services, one organisation believed that the passing of the Bill would lead to an increased demand for such services. Most other organisations, however, felt the demand was not significant - or in some cases made the point that the internal systems for processing cases was English-language-based. 
Table 8.3 Attitude of economic development bodies

\begin{tabular}{|c|c|c|c|c|c|c|c|}
\hline \multirow[b]{2}{*}{ Question } & \multicolumn{4}{|c|}{ Local enterprise companies (LECs) } & \multicolumn{2}{|c|}{ Divisions/ teams } & \multirow{2}{*}{$\begin{array}{c}\text { Council } \\
\text { WI Council }\end{array}$} \\
\hline & WIE & SLE & Lochaber & Inverness/NE & Culture/Heritage & Data & \\
\hline $\begin{array}{l}\text { Does the } \\
\text { organisation have } \\
\text { a specific } \\
\text { language policy } \\
\text { (or plan to have } \\
\text { one)? }\end{array}$ & $\begin{array}{l}\text { Same as HIE } \\
\text { network }\end{array}$ & $\begin{array}{l}\text { No- other than } \\
\text { the Gaelic } \\
\text { Language Bill } \\
\text { when it comes } \\
\text { out }\end{array}$ & $\begin{array}{l}\text { No specific policy } \\
\text { apart from HIE } \\
\text { network policy }\end{array}$ & $\begin{array}{l}\text { Dependent on } \\
\text { core HIE level }\end{array}$ & $\begin{array}{l}\text { Not language } \\
\text { policy but Gaelic } \\
\text { policy }\end{array}$ & $\begin{array}{l}\text { Dependent on } \\
\text { core HIE level }\end{array}$ & $\begin{array}{l}\text { Council has very } \\
\text { detailed Gaelic } \\
\text { language Policy }\end{array}$ \\
\hline $\begin{array}{l}\text { Do members of } \\
\text { staff have specific } \\
\text { knowledge of } \\
\text { language- } \\
\text { planning issues? }\end{array}$ & $\begin{array}{l}\text { Yes of six in } \\
\text { 'strengthening } \\
\text { communities' } \\
\text { team, three are } \\
\text { involved in } \\
\text { developing } \\
\text { language policy }\end{array}$ & $\begin{array}{l}\text { One member } \\
\text { (through personal } \\
\text { commitment) }\end{array}$ & No & $\begin{array}{l}\text { Others probably } \\
\text { not, but } \\
\text { respondent yes }\end{array}$ & $\begin{array}{l}\text { Yes, members of } \\
\text { Cultural Heritage } \\
\text { team }\end{array}$ & $\begin{array}{l}\text { One or two } \\
\text { heavily } \\
\text { involved on } \\
\text { personal level, } \\
\text { nothing linked } \\
\text { to job }\end{array}$ & $\begin{array}{l}\text { 'Quite a few' } \\
\text { coordinate with } \\
\text { those developing } \\
\text { Language Plan for } \\
\text { Western Isles }\end{array}$ \\
\hline $\begin{array}{l}\text { Does the } \\
\text { organisation have } \\
\text { an attitude to the } \\
\text { issue of bilingual } \\
\text { staff / training in } \\
\text { the minority } \\
\text { language / } \\
\text { instances where } \\
\text { the minority } \\
\text { language 'ought' } \\
\text { to be used? }\end{array}$ & $\begin{array}{l}\text { Not a } \\
\text { prerequisite; } \\
\text { one problem is } \\
\text { all systems/ } \\
\text { proformas are } \\
\text { English- } \\
\text { medium-based }\end{array}$ & $\begin{array}{l}\text { Not a } \\
\text { prerequisite; } \\
\text { courses/support } \\
\text { offered; staff } \\
\text { encouraged }\end{array}$ & $\begin{array}{l}\text { No; in five years } \\
\text { only three written } \\
\text { enquiries in Gaelic; } \\
\text { most work is in } \\
\text { partnership with } \\
\text { local councils; no } \\
\text { request for use of } \\
\text { Gaelic }\end{array}$ & $\begin{array}{l}\text { Not a } \\
\text { prerequisite; } \\
\text { courses/support } \\
\text { offered; staff } \\
\text { encouraged }\end{array}$ & $\begin{array}{l}\text { Not a } \\
\text { prerequisite; } \\
\text { courses/support } \\
\text { offered; staff } \\
\text { encouraged }\end{array}$ & $\begin{array}{l}\text { Not a } \\
\text { prerequisite; } \\
\text { courses/support } \\
\text { offered; staff } \\
\text { encouraged, } \\
\text { though } \\
\text { practical use } \\
\text { limited }\end{array}$ & $\begin{array}{l}\text { Not a prerequisite; } \\
\text { however, most } \\
\text { adverts now put } \\
\text { 'Gaelic essential' } \\
\text { or 'Gaelic } \\
\text { desirable' }\end{array}$ \\
\hline $\begin{array}{l}\text { Does the } \\
\text { organisation keep } \\
\text { records of the } \\
\text { staff's language } \\
\text { abilities? }\end{array}$ & $\begin{array}{l}\text { Only in terms of } \\
\text { job applications }\end{array}$ & No & $\begin{array}{l}\text { No - but } \\
\text { informally } \\
\text { linguistic abilities } \\
\text { are known (small } \\
\text { office) }\end{array}$ & $\begin{array}{l}\text { No - never been } \\
\text { asked }\end{array}$ & $\begin{array}{l}\text { Suggestion was } \\
\text { rejected by HR } \\
\text { team - possibly a } \\
\text { 'sensitivity' about } \\
\text { enquiring into } \\
\text { staff's linguistic } \\
\text { abilities? }\end{array}$ & $\begin{array}{l}\text { No, but are } \\
\text { aware of it }\end{array}$ & $\begin{array}{l}\text { Not to } \\
\text { respondent's } \\
\text { knowledge }\end{array}$ \\
\hline $\begin{array}{l}\text { Estimate of the } \\
\text { percentage of } \\
\text { bilingual staff }\end{array}$ & $45 \%$ of 25 staff & $\begin{array}{l}\text { Possibly one } \\
\text { fluent out of } 13 \text {, } \\
\text { with two others } \\
\text { having some }\end{array}$ & $\begin{array}{l}\text { Two out of } 17 \text { have } \\
\text { some ability }\end{array}$ & $\begin{array}{l}10 \% \text { (two), plus } \\
25 \% \text { with some } \\
\text { interest }\end{array}$ & $\begin{array}{l}\text { Has declined in } \\
\text { last five years (so } \\
\text { have staff } \\
\text { numbers) }\end{array}$ & $50 \%$ & $\begin{array}{l}\text { In division, } \\
\text { approx. } 70 \%\end{array}$ \\
\hline
\end{tabular}




\begin{tabular}{|c|c|c|c|c|c|c|c|}
\hline & & knowledge & & & & & \\
\hline $\begin{array}{l}\text { Are staff } \\
\text { encouraged to } \\
\text { become } \\
\text { bilingual? }\end{array}$ & $\begin{array}{l}\text { Demand-led, } \\
\text { rather than } \\
\text { supply-led } \\
\text { presumption } \\
\text { that you ought } \\
\text { to be bilingual }\end{array}$ & $\begin{array}{l}\text { Yes - open-door } \\
\text { policy (if demand } \\
\text { made); demand- } \\
\text { led }\end{array}$ & $\begin{array}{l}\text { Not really; } \\
\text { demand-led }\end{array}$ & $\begin{array}{l}\text { Informally } \\
\text { supported; } \\
\text { courses } \\
\text { supported; } \\
\text { demand-led }\end{array}$ & $\begin{array}{l}\text { Some posts have } \\
\text { prerequisite of } \\
\text { being bilingual; } \\
\text { previous practice } \\
\text { was not to put this } \\
\text { requirement 'up } \\
\text { front'; becoming } \\
\text { bilingual is } \\
\text { informally } \\
\text { supported; } \\
\text { courses supported }\end{array}$ & $\begin{array}{l}\text { Not } \\
\text { particularly; } \\
\text { work is } \\
\text { technical (data- } \\
\text { driven); would } \\
\text { be demand-led }\end{array}$ & $\begin{array}{l}\text { Yes; new staff } \\
\text { always } \\
\text { encouraged; help } \\
\text { given with courses }\end{array}$ \\
\hline $\begin{array}{l}\text { Perceived } \\
\text { problems in } \\
\text { expecting staff to } \\
\text { be bilingual? }\end{array}$ & $\begin{array}{l}\text { Personal view } \\
\text { that Gaelic } \\
\text { speakers could } \\
\text { fill all posts; } \\
\text { others believe } \\
\text { this might limit } \\
\text { the field }\end{array}$ & $\begin{array}{l}\text { Have to advertise } \\
\text { two or three times } \\
\text { for adequate } \\
\text { technical staff } \\
\text { irrespective of } \\
\text { linguistic ability; } \\
\text { would make it } \\
\text { even harder }\end{array}$ & $\begin{array}{l}\text { Time commitment } \\
\text { to training existing } \\
\text { staff; sourcing } \\
\text { Gaelic speakers } \\
\text { with adequate } \\
\text { skills }\end{array}$ & $\begin{array}{l}\text { Difficult local } \\
\text { labour market } \\
\text { conditions - } \\
\text { hard to attract } \\
\text { staff }\end{array}$ & $\begin{array}{l}\text { Gaelic ability } \\
\text { desirable rather } \\
\text { than 'bilingual' } \\
\text { being required; } \\
\text { otherwise is felt } \\
\text { to 'restrict' field } \\
\text { for 'higher' staff }\end{array}$ & $\begin{array}{l}\text { Personal view } \\
\text { that no } \\
\text { problems in } \\
\text { getting Gaelic } \\
\text { speakers for } \\
\text { jobs; however, } \\
\text { it might } \\
\text { discourage in- } \\
\text { migration }\end{array}$ & $\begin{array}{l}\text { Personal view is } \\
\text { 'no'; real-time } \\
\text { arguments raised } \\
\text { include problems } \\
\text { with equal } \\
\text { opportunities, and } \\
\text { field of candidates } \\
\text { available }\end{array}$ \\
\hline $\begin{array}{l}\text { Does the } \\
\text { promotion of } \\
\text { GLAC feature in } \\
\text { the aims of the } \\
\text { organisation? If } \\
\text { so, what level of } \\
\text { importance does } \\
\text { it have? }\end{array}$ & $\begin{array}{l}\text { Yes; is key to } \\
\text { project } \\
\text { appraisal; } \\
\text { personally } \\
\text { thinks 'very } \\
\text { important'; } \\
\text { other staff may } \\
\text { think it only } \\
\text { 'important' }\end{array}$ & $\begin{array}{l}\text { Yes - in the } \\
\text { 'strengthening } \\
\text { communities' } \\
\text { commitment; it's } \\
\text { of 'some/little' } \\
\text { consequence }\end{array}$ & $\begin{array}{l}\text { Yes, through } \\
\text { support to Fèis } \\
\text { (festival) } \\
\text { movement and } \\
\text { focus on creative } \\
\text { industries, plus } \\
\text { work of prominent } \\
\text { Gaelic supporters } \\
\text { on local council }\end{array}$ & $\begin{array}{l}\text { Yes (this is } \\
\text { new); previously } \\
\text { only 'formal'; is } \\
\text { 'important' due } \\
\text { to 'strengthening } \\
\text { communities' } \\
\text { policy }\end{array}$ & $\begin{array}{l}\text { Yes, but } \\
\text { 'promotion' } \\
\text { probably the } \\
\text { wrong word; } \\
\text { guided by } \\
\text { Scottish } \\
\text { Executive } \\
\text { position ('Smart } \\
\text { Successful } \\
\text { Scotland'); } \\
\text { probably 'of some } \\
\text { importance' }\end{array}$ & $\begin{array}{l}\text { Not applicable } \\
\text { to data- } \\
\text { processing } \\
\text { work }\end{array}$ & $\begin{array}{l}\text { Yes, very } \\
\text { important }\end{array}$ \\
\hline $\begin{array}{l}\text { Does a client } \\
\text { body's attitude to } \\
\text { GLAC feature in } \\
\text { whether it might } \\
\text { be funded, and to }\end{array}$ & $\begin{array}{l}\text { Everything } \\
\text { examined on } \\
\text { individual } \\
\text { merit; if two } \\
\text { projects differed }\end{array}$ & It is a factor & $\begin{array}{l}\text { More so with } \\
\text { community-based } \\
\text { schemes }\end{array}$ & $\begin{array}{l}\text { Not particularly; } \\
\text { neither do you } \\
\text { often get two } \\
\text { identical } \\
\text { requests in }\end{array}$ & $\begin{array}{l}\text { Equal treatment; } \\
\text { Scottish } \\
\text { Executive } \\
\text { isagainst } \\
\text { 'positive' action }\end{array}$ & $\mathrm{N} / \mathrm{a}$ & $\begin{array}{l}\text { No; applications } \\
\text { judged on overall } \\
\text { merit (though } \\
\text { have criteria on } \\
\text { which GLAC }\end{array}$ \\
\hline
\end{tabular}




\begin{tabular}{|c|c|c|c|c|c|c|c|}
\hline $\begin{array}{l}\text { what level? What } \\
\text { criteria are } \\
\text { involved in } \\
\text { funding } \\
\text { decisions? }\end{array}$ & $\begin{array}{l}\text { only in } \\
\text { linguistic } \\
\text { implications, } \\
\text { Gaelic would be } \\
\text { seen as positive } \\
\text { factor }\end{array}$ & & & $\begin{array}{l}\text { different } \\
\text { languages to } \\
\text { choose between }\end{array}$ & & & $\begin{array}{l}\text { projects can } \\
\text { apply) }\end{array}$ \\
\hline $\begin{array}{l}\text { Does any } \\
\text { monitoring of the } \\
\text { language impact } \\
\text { of funding } \\
\text { decisions take } \\
\text { place? }\end{array}$ & $\begin{array}{l}\text { This will } \\
\text { increasingly } \\
\text { happen through } \\
\text { work on } \\
\text { Western Isles } \\
\text { language plan }\end{array}$ & $\begin{array}{l}\text { No - though try } \\
\text { to monitor } \\
\text { creation of } \\
\text { 'cultural/ } \\
\text { community } \\
\text { assets, tangible } \\
\text { and intangible' }\end{array}$ & $\begin{array}{l}\text { If agreed outputs } \\
\text { involved this, they } \\
\text { would be } \\
\text { monitored }\end{array}$ & $\begin{array}{l}\text { Only if agreed } \\
\text { in the aims of } \\
\text { the contract; } \\
\text { hasn't happened } \\
\text { yet }\end{array}$ & $\begin{array}{l}\text { Only if agreed in } \\
\text { the aims of the } \\
\text { contract }\end{array}$ & $\mathrm{N} / \mathrm{a}$ & $\begin{array}{l}\text { No; are } \\
\text { overstretched; } \\
\text { most monitoring is } \\
\text { financial }\end{array}$ \\
\hline $\begin{array}{l}\text { Is it possible to } \\
\text { determine the } \\
\text { proportion of } \\
\text { monies/aid given } \\
\text { to GLAC-related } \\
\text { organizations? }\end{array}$ & $\begin{array}{l}\text { No way of } \\
\text { breaking it } \\
\text { down in the } \\
\text { system }\end{array}$ & $\begin{array}{l}\text { Perhaps less than } \\
5 \% \text { of total } \\
\text { budget }\end{array}$ & $\begin{array}{l}\text { Depends year to } \\
\text { year; depends on } \\
\text { importance of } \\
\text { 'strengthening } \\
\text { communities' } \\
\text { budget }\end{array}$ & $\begin{array}{l}\text { Difficult to do so } \\
\text { - varies } \\
\text { incredibly year } \\
\text { to year }\end{array}$ & $\begin{array}{l}\text { Difficult to do so } \\
\text { - varies greatly; } \\
\text { in some years } \\
\text { may be } \\
\text { substantial }\end{array}$ & N/a & $\begin{array}{l}\text { Very difficult to } \\
\text { do so }\end{array}$ \\
\hline $\begin{array}{l}\text { What are your } \\
\text { personal views on } \\
\text { the importance of } \\
\text { GLAC for the } \\
\text { social and for the } \\
\text { economic } \\
\text { development of } \\
\text { the area? }\end{array}$ & $\begin{array}{l}\text { Of great } \\
\text { importance for } \\
\text { both; personally } \\
\text { believe more } \\
\text { can be done } \\
\text { proactively }\end{array}$ & $\begin{array}{l}\text { Some importance } \\
\text { to social } \\
\text { development; of } \\
\text { little importance } \\
\text { to economic } \\
\text { development }\end{array}$ & $\begin{array}{l}\text { Of great } \\
\text { importance for } \\
\text { social } \\
\text { development; of } \\
\text { little importance to } \\
\text { economic } \\
\text { development (only } \\
\text { has oblique link to } \\
\text { tourism) }\end{array}$ & $\begin{array}{l}\text { Of great } \\
\text { importance for } \\
\text { social } \\
\text { development; of } \\
\text { some importance } \\
\text { for economic } \\
\text { development }\end{array}$ & $\begin{array}{l}\text { Of some } \\
\text { importance for } \\
\text { both; perceives } \\
\text { growing support } \\
\text { from the public in } \\
\text { both areas }\end{array}$ & $\begin{array}{l}\text { Of great } \\
\text { importance for } \\
\text { social } \\
\text { development; } \\
\text { of some } \\
\text { importance for } \\
\text { economic } \\
\text { development }\end{array}$ & $\begin{array}{l}\text { Of great } \\
\text { importance for } \\
\text { both; thinks most } \\
\text { believe it has } \\
\text { 'some } \\
\text { importance'; this } \\
\text { will improve in } \\
\text { personal view }\end{array}$ \\
\hline
\end{tabular}


GLAC Gaelic language, arts and culture HIE Highlands and Islands Enterrprise SIE Skye and Lochalsh Enterprise WIE Western Isles Enterpise 
Having suggested that there was insubstantial demand for Gaelic-medium services, almost all organisations however, subscribed to the view that one aspect of their own work was to promote Gaelic language, arts and culture. Nevertheless there did not yet seem to be any recognised mechanism in place for assessing the language impact of a potential project, or the general cultural impact - unless it was written in as an aim in the funding application (e.g. 'create twenty Gaelic-speaking playgroup jobs'). But in this respect the situation was no different from that regarding other funding applications.

Additionally, although some parts of the network suggested there would be 'positive action' in favour of a Gaelic-linked application if a choice had to be made between two such projects, differing only in their language implications, others said it is never as clear-cut as that. In general it would depend on each individual case and how it fitted into network priorities at any time. It was also reported that some officials in the Scottish Government would be scandalised at the thought of such positive action, fearing a backlash in terms of press coverage.

In terms of the importance ascribed to Gaelic language, arts and culture for the social and for the economic development of their geographical area, amongst respondents this varied greatly with most agreeing 'some' or 'great' importance for social development, but most suggesting it was only of 'some' or of 'little' importance for economic development (however, those within the Western Isles ascribed great importance to this concept for social and economic development).

\section{Interview with chief executive of the Bòrd na Gaidhlig}

The findings of these preliminary discussions were further discussed with the chief executive of the Bòrd na Gàidhlig, who concurred with the view that insufficient work had been done in terms of policy makers' exploration of the dynamic interconnections between economic development and language advance or retreat. His view was that very little consideration (if any) was presently given by enterprise and development agencies to possible negative impacts on the language of ill-thought-out possibilities. Similarly, possible positive synergies between both fields were underdeveloped. He felt that at present very few businesses 
operated in a Gaelic environment. This aspect needed development, with close attention to marketing the unique selling points it might provide.

He felt that a problem, in the enterprise companies and elsewhere, was that even where there was a good language policy (and it might be signed up to by chairs of local bodies), the officers on the ground often knew nothing about it whatsoever - or relegated it to the community development team. It was necessary for this to change, and an opportunity now presented itself with the need for public bodies to initiate language plans.

The Bòrd na Gàidhlig was to meet with ten public bodies per year (once sufficient staff had been recruited) and help them come up with workable plans. The idea then was to make sure that every member of the workforce was aware of the plans and involved in their implementation.

In his view a key new aspect of the language plans was the focus on the potential for development by the use of Gaelic, rather than on the percentage of current service users who presently spoke Gaelic - which was good.

\section{The view of the Gaelic Arts Agency}

Arts development has been closely linked both to language development and to economic development for over a decade in relation to Gaelic (see Sproull and Ashcroft, 1993; Chalmers, 2003; Beattie, Westbrook et al., 2004; Pedersen Consulting and Hecla Consulting, 2004), one of the most successful recent initiatives being the venture of Pròiseact nan Ealan, An Leabhear Mòr - the Big Book of Gaelic (www.leabharmor.net).

Increasing acknowledgement of the need to strategically plan the development of the Gaelic arts and their interconnection with vibrant communities and the Gaelic language itself led to the formation of the Gaelic Arts Strategic Development (GASD) forum in 2001. Formed from some of the main groups active in this area - Pròiseact nan Ealan (the Gaelic Arts Agency), Fèisean nan Gàidheal (the Gaelic Fèis (festival) development body), TOSG 
(Theatre of Scottish Gaelic), Comhairle non Leabhraichean (Gaelic Books Council), An Communn Gàidhealach (organisers of the annual Gaelic Royal 'Mod' festival) and Seirbheis nam Meadhanan Gàidhlig (Gaelic Media Services - the body in charge of commissioning Gaelic television programmes), GASD aims to provide a collective voice for the Gaelic arts sector.

Its main aim is stated as 'enhancing the profile of Gaelic arts and artists, increasing audiences and building support in the wider community for the Gaelic language'.

Within this professed remit, it acknowledges as one of the four primary roles of the Gaelic arts sector 'its economic role in providing employment for artists and benefits to Gaelic communities'. However, it also highlights the Gaelic arts sector's 'learning role in encouraging the role of the language'. Identified as a main focus for its programme implementation is skills development within the sector.

Pròiseact nan Ealan and GASD therefore place themselves at the interface between arts, the language and economic development - something that lends weight to their consideration of the uneasy tension between economics and language mentioned within this chapter. In a discussion of these issues with the author, Calum MacLean, director of the Gaelic Arts Agency, suggested that one positive result of the last decade's work by the Gaelic artistic community was that very significant positive shifts were now apparent in public attitudes towards Gaelic. These attitudes existed well beyond the Gaelic community itself. Now that the principle of language planning had been accepted by the Scottish Parliament, and Gaelicmedium education had become more entrenched, together with strong recognition of the benefits of Gaelic broadcasting, this pushed onto centre stage the need for understanding the dynamics of Gaelic language regeneration. It was necessary to investigate to a more profound extent the links between cultural promotion, individual and community experience, identity, and the integration of these with language learning. While it might be comparatively simple 
to understand the general principles of language planning, the second, harder step was to design viable strategies - how to move the debate on to a more focused, more vigorous context. The area that needed more examination was the question of what led people to choose one language rather than another. Motivation was the key, and a good simile might be the issue of electricity, where the correct cabling and wiring infrastructure was necessary but the cabling itself did not explain the existence of electricity. Improving the status of the Gaelic language was a crucial issue, but in some ways this was a plug-and-socket approach, when the question was how to give the network 'life'. In regard to this issue, arts and culture were undoubtedly major motivational forces in life making these work for language development was key. He suggested two different challenges - firstly the question of motivation within the Gaelic community (to individuals' linguistic, social and economic benefit). Secondly there was the wider question of the non-Gaelic community. This needed to draw upon a huge number of policy makers who were not Gaelic speakers. Arts and culture could help create the interface - the most accessible point. Thus in his view, as well as providing a possible immediate direct benefit to those within the Gaelic artistic and cultural community, by drawing a percentage of income into the community, and thus increasing the critical mass of those who can provide exposure, the arts and cultural field also provided the best window onto the world in terms of drawing others to the world of Gaelic. In terms of this, one could cite the Leabhar Mòr exhibition, which was displayed in eight locations in the UK, received 20 metres of press coverage, including 26 different articles, and seven or eight different media pieces. This was an example of positive media coverage, which, if it had had to be paid for by buying space to promote the language, would have involved an exorbitant cost. Of other measurable outputs, although just over 6,000 Glaswegians speak Gaelic, some 25,000 visited the exhibition in the Gallery of Modern Art. 
This was a good example of inclusivity and of providing a positive face to the world for Gaelic.

\section{Conclusions}

Williams (this volume, Chapter 6) refers to the dilemma of language choice, and the attraction of the path of least resistance. To adopt the language of the economist, the individual may be expected to act as 'rational economic man' (sic) in weighing up the costs and benefits of any action. This chapter has outlined an increasing understanding of the measurable benefits of a better integration of the economic, the cultural and the linguistic, thus allowing a 'rational' choice which may increasingly benefit the minority language community. Gaelic Scotland is a clear case where policy makers have come only belatedly to the consideration of such positive linkages, despite some long-term evidence of this understanding being held by a large proportion of the Gaelic-speaking and non-Gaelicspeaking community in the Western Isles and Skye and Lochalsh, including sections of business based there. Williams' plea for the collection of more data, including that regarding the economic demand for a bilingual workforce, is very relevant in this regard, however - the absence of 'hard' as opposed to 'soft' data based on perceptions considerably weakens any economic case being made for the full integration of linguistic aspects of local development. There is clearly the need for further research in this area - the collection and collation of upto-date and accurate information on the existing baseline of employment, where knowledge of the minority language is essential or seen as desirable, would immeasurably help situate this debate within a more robust framework.

Some important criticism from parts of the language development community regarding what they see as the 'rhetoric' of this debate is also acknowledged within this chapter. This again is an area that would clearly benefit from further research and dialogue between the arts and cultural community and those concerned with linguistic development. 
It is in examining further evidence about policy practice in the 'Gaelic economy' that we may expect that the greatest positive shifts may come about in the short to medium term. Currently, as this chapter shows, any acknowledgement at an official level of issues of language planning or linguistic impact could only be categorised as minimal within economic development agencies during the period of research undertaken by this author. Clearly agencies such as the Bòrd na Gàidhlig and particularly the Gaelic Arts Agency continue to hold a more holistic and nuanced view than the economic development agencies of the complex relationship between arts and culture, employment and language policy, and how a positive synergy can be created between them. However, with the increasing recognition now formally being given to the importance of Gaelic language, arts and culture by economic development agencies and officials and the much higher profile that will be given to the language following the passing of the Gaelic Language Bill, and the launch of the dedicated Gaelic Digital Channel on the airwaves in 2008, acknowledgement of the bilingual reality of some of the most underdeveloped parts of Scotland will be impossible to ignore.

\section{Notes}

1 Local arts and music tuition festivals featuring the Gaelic arts.

2 Something which was about to be qualitatively expanded only 15 years later, in 2008 , with the instigation of a Gaelic digital television channel, run in collaboration by the BBC and Gaelic Media Services.

3 Comparison with the relevant national Census figures suggested a profile of respondents that was extremely close to the general population of that area in key characteristics. If anything, there was an underrepresentation of individuals who might have been expected to be positively biased in relation to minority language issues - i.e. there was a smaller percentage of fluent speakers among the questionnaire respondents than in fact existed in the area, according to the Census. 